\title{
JEKK
}

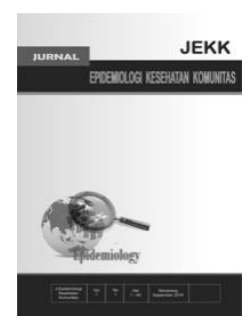

\section{Hubungan Gaya Hidup dengan Kesehatan Mental Remaja di Indonesia (Analisis Data Global School-Based Student Health Survey Indonesia 2015)}

\author{
Silfia Dini Pratiwi*, Ratna Djuwita* \\ *Program Studi Magister Epidemiologi, Fakultas Kesehatan Masyarakat, Universitas Indonesia, \\ ${ }^{* *}$ Departemen Epidemiologi, Fakultas Kesehatan Masyarakat, Universitas Indonesia
}

\begin{abstract}
Background: Mental health disorders are one of the main risk factors for causing pain and death in adolescents. Symptoms of mental health disorders can be anxiety, depression, sleep disorders, suicidal or self-harm ideas, and attempted suicide. Poor mental health is a severe health problem, especially in adolescents. Mental health is affected by multiple factors, including daily behavior and individual lifestyle.

Methods: This study aimed to find out the relationship between lifestyle and mental health of adolescents in Indonesia. This study used secondary data from Indonesia's Global School-Based Student Health Survey in 2015. The population of this study was 9.628 students aged 11-18 years in Indonesia. This research sample was obtained by the total sampling method. This study used multivariate analysis of cox regression and large associations expressed with Prevalence Ratio (PR) with $95 \%$ Confidence Interval.

Result: The prevalence of adolescents in Indonesia with mental health disorders is $9,4 \%$. Multivariate analysis test results showed there was a significant relationship between lifestyle and adolescent mental health in Indonesia (PR=1,47, 95\% CI: 1,31 - 1,65) after being controlled by gender, socioeconomic status, and bullying.
\end{abstract}

Conclusion : The school and parents are advised to work together to prevent mental health disorders in adolescents.

Keywords : Mental Health; Mental Health Disorders; Lifestyle; Adolescent.

*Penulis korespondensi, silfia.dini@ui.ac.id 


\section{Pendahuluan}

Dalam beberapa tahun terakhir, kesehatan mental telah dianggap penting untuk mencapai tujuan pembangunan global yaitu dengan dimasukannya kesehatan mental dalam SDG (Sustainable Development Goals). ${ }^{1}$ Kondisi gangguan kesehatan mental meningkat di seluruh dunia, ada kenaikan $13 \%$ kondisi gangguan kesehatan mental dan penyalahgunaan zat terlarang pada beberapa dekade terakhir hingga tahun 2017. Kondisi gangguan kesehatan mental dapat menyebabkan 1 dari 5 tahun hidup dengan kecacatan. Gangguan kesehatan mental menyumbang sekitar 14\% pada beban penyakit global, dengan depresi dan kecemasan sebagai penyebab disabilitas di seluruh dunia. ${ }^{2}$

Kesehatan mental yang terganggu merupakan salah satu faktor risiko utama penyebab kesakitan dan kematian pada remaja. ${ }^{3}$ Gejala gangguan mental dapat berupa ansietas atau kecemasan, depresi, gangguan tidur, ide bunuh diri atau menyakiti diri sendiri dan percobaan bunuh diri. ${ }^{4}$ Kondisi mental yang buruk merupakan masalah kesehatan yang berat, khususnya pada remaja dan sebagian besar masalah kesehatan mental dimulai sejak usia 14 tahun.

Kesehatan mental dipengaruhi oleh berbagai faktor, termasuk perilaku sehari-hari yang dapat diubah oleh individu. ${ }^{5}$ Informasi mengenai pengaruh gaya hidup terhadap gejala depresi dan gangguan kesehatan mental lainnya masih sedikit. ${ }^{6}$ Gaya hidup sehat dapat mengurangi kerentanan remaja terhadap stres dan dapat meningkatkan kesejehateraan mental. ${ }^{7,8}$ Kerangka hasil tentang penelitian kesehatan masyarakat di Inggris menyatakan bahwa program gaya hidup sehat yang bertujuan untuk meningkatkan aktivitas fisik dan memperbaiki pola makan atau diet, dapat meningkatkan kesehatan mental. ${ }^{2}$ Sedangkan penelitian Ferreira (2016) menyebutkan bahwa remaja pada tingkat akhir lebih memiliki kemungkinan untuk tidak bergerak (perilaku menetap). Remaja pada masa ini kemungkinan memiliki lebih banyak mata pelajaran dan tekanan akademis yang besar sehingga memperpanjang waktu duduk mereka dan menggantikan waktu untuk aktivitas fisik. ${ }^{9}$
Gaya hidup yang tidak sehat seperti konsumsi alkohol dan merokok meningkatkan risiko keinginan bunuh diri. ${ }^{7}$ Gaya hidup yang berisiko lebih cenderung berhubungan dengan usia muda atau remaja, jenis kelamin laki-laki, tingkat pendidikan yang rendah, dan gangguan mental. Selain itu, gaya hidup yang berisiko berhubungan dengan kesehatan yang dinilai diri sendiri. Misalnya, kondisi kesehatan yang positif berkorelasi dengan tidak atau minim konsumsi alkohol dan merokok, serta dengan gizi yang sehat dan aktivitas fisik yang tinggi. ${ }^{10}$ Penelitian yang dilakukan oleh Hoare menyatakan bahwa seseorang yang memiliki gangguan kesehatan mental lebih cenderung mengkonsumsi makanan yang tidak sehat sehingga mempengaruhi berat badan. Perilaku berisiko yang didapat pada saat remaja dapat berlanjut hingga dewasa. ${ }^{11}$

Penelitian mengenai kesehatan mental remaja cukup banyak. Namun, penelitian mengenai gaya hidup terkait kesehatan mental masih kurang. Penelitian ini bertujuan mengetahui hubungan gaya hidup dengan kesehatan mental remaja di Indonesia berdasarkan GSHS tahun 2015. Sehingga dapat digunakan sebagai acuan untuk upaya pencegahan dan mengatasi gangguan kesehatan mental remaja di Indonesia.

\section{Metode}

Penelitian ini menggunakan desain crosssectional dengan pendekatan kuantitatif menggunakan data sekunder GSHS tahun 2015. GSHS Indonesia tahun 2015 menggunakan teknik two-stage cluster sampling (sekolah dan kelas). Pemilihan sampel sekolah pada GSHS Indonesia 2015 menggunakan "PC Sample School Selection Algorithm" sehingga diperoleh total sekolah sebanyak 75 sekolah dari 3 wilayah di Indonesia meliputi Sumatra, JawaBali, Luar Sumatra Jawa-Bali dalam 26 provinsi dan 68 kabupaten/kota di Indonesia dan pemilihan sampel kelas menggunakan teknik systematic sampling. Populasi target pada penelitian ini adalah seluruh remaja sekolah tingkat SMP dan SMA berusia 11-18 tahun di Indonesia pada tahun 2015. Populasi sumber adalah remaja sekolah tingkat SMP dan SMA berusia 11-18 tahun di Indonesia yang menjadi responden dalam Global School-Based Student 
Health Survey Indonesia tahun 2015, yaitu sebesar 11.142. Populasi eligible adalah remaja sekolah tingkat SMP dan SMA usia 11-18 tahun di Indonesia yang menjadi responden dalam Global School-Based Student Health Survey
Indonesia tahun 2015 dan memenuhi kriteria inklusi penelitian, yaitu 9.682 anak SMP-SMA. Populasi eligible akan masuk dalam penelitian (Gambar 1).

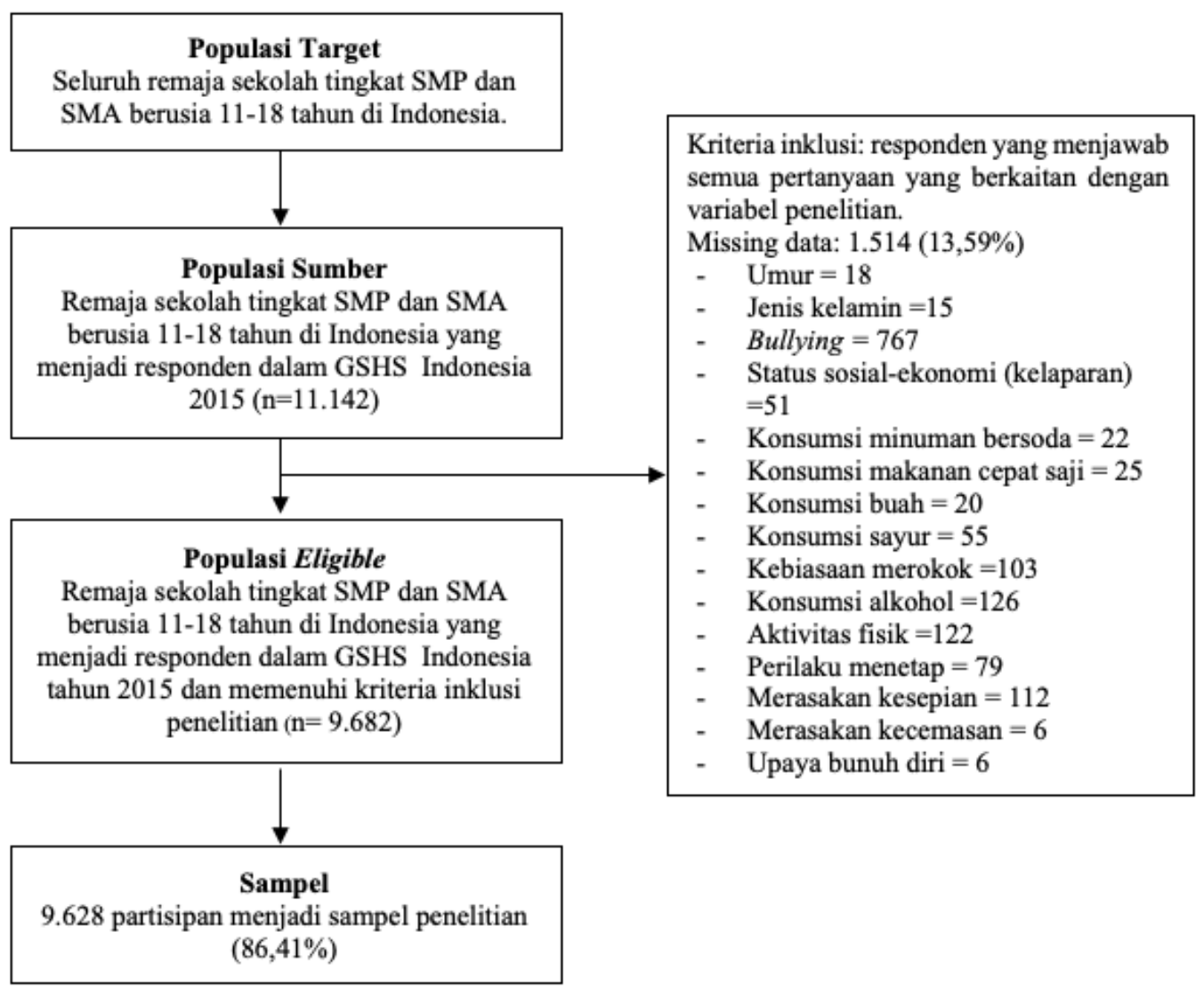

Gambar 1. Alur Pemilihan Sampel

Variabel independen pada penelitian ini adalah gaya hidup. Variabel gaya hidup merupakan komposit dari 8 variabel, yaitu: konsumsi buah, konsumsi sayur, konsumsi makanan cepat saji, konsumsi minuman berkarbonasi, kebiasaan merokok, konsumsi alkohol, aktivitas fisik, dan perilaku menetap. Skor maksimal dari variabel gaya hidup adalah 8. Nilai skoring dari 8 variabel akan diakumulasi dan dirata-rata untuk setiap responden. Selanjutnya akan dilakukan uji analisis normalitas pada data tiap responden menggunakan uji normalitas Skewness \& Kurtosis dan diperoleh hasil bahwa data tidak terdistribusi normal ( $\mathrm{P}<0,05)$ sehingga pengkategorian variabel gaya hidup ditentukan dengan nilai median. Gaya hidup akan dikategorikan menjadi gaya hidup tidak sehat jika total skor responden $\leq$ median dan gaya hidup sehat jika total skor responden $>$ median.

Variabel kesehatan mental pada penelitian ini adalah komposit dari variabel kesepian (kondisi pelajar hampir setiap saat/selalu merasa kesepian), variabel kecemasan (kondisi pelajar hampir setiap saat/selalu merasa khawatir hingga sulit tidur) dan variabel upaya bunuh diri (kondisi pelajar yang $\geq 1$ kali pernah melakukan upaya bunuh diri) yang dirasakan dalam 12 bulan terakhir. ${ }^{12}$ Kemudian kesehatan mental akan dikategorikan memiliki gangguan kesehatan mental jika skor total responden $\geq 1$ dan tidak memiliki gangguan kesehatan mental jika skor total responden $\leq 1$. $^{12}$

Variabel kovariat pada penelitian ini terdiri dari umur, jenis kelamin, status sosialekonomi dan bullying. Umur dikelompokan 
menjadi kelompok umur 11-14 tahun dan 15-18 tahun dan jenis kelamin (laki-laki dan perempuan). Pada GSHS Indonesia tidak terdapat variabel mengenai status sosialekonomi. Namun berdasarkan penelitian Hasumi et al., mengalami kelaparan dapat dijadikan sebagai proksi status sosialekonomi. ${ }^{13}$ Status sosial-ekonomi pada penelitian ini dilihat dari variabel mengalami kelaparan dengan pengkategorian status sosialekonomi tinggi menengah (tidak pernah/ jarang/ kadang-kadang mengalami kelaparan) dan status sosial-ekonomi rendah (sering/selalu mengalami kelaparan). Variabel bullying dikategorikan menjadi mengalami bullying dan tidak mengalami bullying. Analisis pada penelitian ini terdiri dari analisis univariat, bivariat dan multivariat. Analis bivariat menggunakan uji chi-square untuk melihat untuk mengetahui kemakanaan hubungan secara statistik. Jika $\mathrm{p}$ value $<0,05$ maka terdapat hubungan bermakna secara statistik. PR digunakan untuk mengetahui derajat hubungan dengan membandingkan risiko pada kelompok terpajan dan kelompok tidak terpajan yaitu dengan menentukan derajat kepercayaan (CI). Analisis multivariat menggunakan analisis cox regresi model kausal dengan confidence interval $95 \%$.

Penelitian ini telah mendapatkan izin dari Komisi Etik Riset dan Pengabdian Masyarakat Fakultas Kesehatan Masyarakat Universitas Indonesia (Nomor: Ket-365/UN2.F10.D11/ PPM.00.02/2021).

Tabel 1. Karakteristik dan Perilaku Remaja di Indonesia

\begin{tabular}{lcc}
\hline \multicolumn{1}{c}{ Karakteristik dan Perilaku Remaja } & N (n=9.628) & Weighted (\%) \\
\hline Umur & & \\
11-14 tahun & 6.057 & $66,82 \%$ \\
15-18 tahun & 3.571 & $33,18 \%$ \\
Jenis Kelamin & & \\
$\quad$ Laki-laki & 4.273 & $47,4 \%$ \\
$\quad$ Perempuan & 5.355 & $52,6 \%$ \\
Status Sosial-Ekonomi & & \\
$\quad$ Tinggi-menengah & 9.248 & $96,05 \%$ \\
$\quad$ Rendah & 380 & $3,95 \%$ \\
Bullying & & $79,9 \%$ \\
$\quad$ Tidak & 7.703 & $20,1 \%$ \\
Ya & 1.925 & \\
\hline
\end{tabular}

\section{Hasil}

Tabel 1 mendeskripsikan mengenai karakteristik dan perilaku gaya hidup remaja di Indonesia. Sebagian besar remaja pada penelitian ini berumur 11-14 tahun $(66,82 \%)$ dan jumlah perempuan $(52,6 \%)$ lebih banyak dari pada laki-laki yaitu $(47,4 \%)$. Mayoritas remaja pada penelitian ini memiliki status sosial-ekonomi adalah pada status sosialekonomi tinggi-menengah $(96,05 \%)$ dan tidak pernah mengalami bullying $(79,9 \%)$.

Berdasarkan komponen gaya hidup, mayoritas remaja pada penelitian ini jarang mengkonsumsi buah $(84,73 \%)$. Sebagian besar remaja sering mengkonsumsi sayur $(57,62 \%)$. Sebanyak $12,12 \%$ remaja sering mengkonsumsi makanan cepat saji. Lebih banyak remaja yang jarang mengkonsumsi makananan cepat saji
(87,88\%). Remaja yang jarang mengkonsumsi minuman berkarbonasi lebih banyak yaitu $(73,28 \%)$ dari pada remaja yang sering mengkonsumsi minuman berkarbonasi $(26,72 \%)$. Mayoritas remaja pada penelitian ini tidak merokok $(89,43 \%)$ dan tidak mengkonsumsi alkohol $(95,14 \%)$. Remaja cenderung kurang melakukan aktivitas fisik $(87,32 \%)$. Sebanyak $28,16 \%$ remaja memiliki perilaku menetap tinggi. Setelah dikomposit 8 variabel di atas, sebagian besar remaja memiliki gaya hidup sehat $(71,84 \%)$ dan sisanya memiliki gaya hidup tidak sehat $(28,16 \%)$ (Tabel 2$)$.

Berdasarkan komponen variabel kesehatan mental, mayoritas remaja pada penelitian ini tidak mengalami kesepian $(94,02 \%)$ dan sisanya $(5,98)$ mengalami kesepian dalam 12 bulan terakhir. Hal serupa 
juga dengan kecemasan, sebanyak 95,72\% remaja pada penelitian ini tidak mengalami kecemasan dalam 12 bulan terakhir sedangkan yang mengalami kecemasan sebesar 4,28\%. Hampir seluruh remaja pada penelitian ini tidak melakukan upaya bunuh diri $(99,26 \%)$ dan
$0,74 \%$ pernah berupaya bunuh diri. Setelah dikomposit 3 variabel di atas, sebanyak 9,4\% remaja pada penelitian ini memiliki gangguan kesehatan mental dan mayoritas remaja di Indonesia tidak memiliki gangguan kesehatan mental (90,6\%) (Tabel 3).

Tabel 2. Gaya Hidup Remaja di Indonesia

\begin{tabular}{lcc}
\hline \multicolumn{1}{c}{ Karakteristik Gaya Hidup Remaja } & N (n=9.628) & Weighted (\%) \\
\hline Konsumsi Buah & & \\
$\quad$ Sering & 1.397 & $15,27 \%$ \\
Jarang & 8.231 & $84,73 \%$ \\
Konsumsi Sayur & & \\
$\quad$ Sering & 5.391 & $57,62 \%$ \\
$\quad$ Jarang & 4.237 & $42,38 \%$ \\
Konsumsi Makanan Cepat Saji & & \\
$\quad$ Jarang & 8.494 & $87,88 \%$ \\
$\quad$ Sering & 1.134 & $12,12 \%$ \\
Konsumsi Minuman Berkarbonasi & & \\
$\quad$ Jarang & 7.048 & $73,28 \%$ \\
$\quad$ Sering & 2.580 & $26,72 \%$ \\
Kebiasaan Merokok & & \\
$\quad$ Tidak Merokok & 8.689 & $89,43 \%$ \\
$\quad$ Merokok & 939 & $10,57 \%$ \\
Konsumsi Alkohol & & \\
$\quad$ Tidak & 9.155 & $95,14 \%$ \\
$\quad$ Ya & 473 & $4,86 \%$ \\
Aktivitas Fisik & & \\
$\quad$ Cukup & 1.212 & $12,68 \%$ \\
$\quad$ Kurang & 8.416 & $87,32 \%$ \\
Perilaku Menetap & & \\
$\quad$ Rendah & & $72,58 \%$ \\
$\quad$ Tinggi & 7.052 & $27,42 \%$ \\
Gaya Hidup & 2.576 & $71,84 \%$ \\
$\quad$ Sehat & & $28,16 \%$ \\
$\quad$ Tidak Sehat & 6.902 &
\end{tabular}

Tabel 3. Kesehatan Mental Remaja di Indonesia

\begin{tabular}{lcc}
\hline \multicolumn{1}{c}{ Karakteristik Kesehatan Mental Remaja } & N (n=9.628) & Weighted (\%) \\
\hline Kesepian & & \\
$\quad$ Tidak & 9.051 & $94,02 \%$ \\
Ya & 577 & $5,98 \%$ \\
Kecemasan & & $95,72 \%$ \\
$\quad$ Tidak & 9.212 & $4,28 \%$ \\
$\quad$ Ya & 416 & $99,26 \%$ \\
Upaya Bunuh Diri & & $0,74 \%$ \\
$\quad$ Tidak & 9.562 & $90,6 \%$ \\
$\quad$ Ya & 66 & $9,4 \%$ \\
Kesehatan Mental & & 8.720 \\
$\quad$ Tidak memiliki gangguan & 908 & \\
Memiliki gangguan &
\end{tabular}


Pada tabel 4, gaya hidup yang merupakan komposit dari 8 variabel (konsumsi buah, konsumsi sayur, konsumsi makanan cepat saji, konsumsi minuman berkarbonasi, kebiasaan merokok, konsumsi alkohol, aktivitas fisik, dan perilaku menetap) memiliki proporsi mengalami gangguan kesehatan mental pada remaja dengan gaya hidup tidak sehat adalah sebesar $12,76 \%$, lebih tinggi dibandingkan proporsi remaja yang memiliki gaya hidup sehat $(8,08 \%)$. Perbedaaan proporsi tersebut signifikan secara statistik ( $p$-value $<0,05)$. Proporsi mengalami gangguan kesehatan mental pada umur 15-18 tahun lebih tinggi $(11,2 \%)$ dari pada umur $11-14$ tahun $(8,5 \%)$. Perbedaaan proporsi tidak tersebut signifikan secara statistik ( $p$-value >0,05). Proporsi mengalami gangguan kesehatan mental mental pada perempuan sedikit lebih tinggi $(9,47 \%)$ dibanding pada laki-laki (9,31\%). Perbedaaan proporsi tersebut tidak signifikan secara statistik ( $p$-value $<0,05)$. Proporsi mengalami gangguan kesehatan mental pada remaja dengan status sosial-ekonomi rendah adalah $24,52 \%$, lebih tinggi dari pada proporsi remaja dengan status sosial-ekonomi tinggi-menengah $(8,79 \%)$. Perbedaan tersebut signifikan secara statistik ( $p$-value < 0,05). Proporsi remaja mengalami gangguan kesehatan mental pada remaja yang mengalami bullying adalah $19,01 \%$ dan pada remaja yang tidak mengalami bullying adalah sebanyak $6,98 \%$. Perbedaan tersebut signifikan secara statistik ( $p$-value $<0,05)$.

Pada tabel 5, variabel yang masuk permodelan akhir multivariat adalah gaya hidup, jenis kelamin, status sosial-ekonomi dan bullying. Hasil analisis multivariat menunjukkan bahwa hubungan gaya hidup tidak sehat dengan mengalami gangguan kesehatan mental secara statistik signifikan dengan PR sebesar 1,47 (95\%CI: 1,31 - 1,65) dan $p$-value = 0,0001 artinya remaja yang memiliki gaya hidup tidak sehat memiliki kecenderungan berisiko 1,47 kali lebih tinggi untuk mengalami gangguan kesehatan mental dibandingkan dengan remaja yang memiliki gaya hidup sehat setelah dikontrol dengan jenis kelamin, status sosial-ekonomi dan bullying.

Tabel 4. Hubungan Karakteristik, Perilaku, dan Gaya Hidup dengan Kesehatan Mental Remaja di Indonesia.

\begin{tabular}{|c|c|c|c|}
\hline \multirow[b]{2}{*}{ Variabel } & \multicolumn{2}{|c|}{ Kesehatan Mental } & \multirow[b]{2}{*}{$p$-value } \\
\hline & $\begin{array}{l}\text { Mengalami } \\
\text { Gangguan }\end{array}$ & $\begin{array}{c}\text { Tidak Mengalami } \\
\text { Gangguan }\end{array}$ & \\
\hline \multicolumn{4}{|l|}{ Gaya Hidup } \\
\hline Tidak Sehat & $346(12,76 \%)$ & $2.380(87,24 \%)$ & 0,0001 \\
\hline Sehat & $562(8,08 \%)$ & $6.340(91,92 \%)$ & \\
\hline \multicolumn{4}{|l|}{ Umur } \\
\hline 15-18 tahun & $394(11,2 \%)$ & $3.177(88,8 \%)$ & \\
\hline 11-14 tahun & $514(8,5 \%)$ & $5.543(91,5 \%)$ & 0,0001 \\
\hline \multicolumn{4}{|l|}{ Jenis Kelamin } \\
\hline Perempuan & $523(9,47 \%)$ & $4.832(90,53 \%)$ & \\
\hline Laki-laki & $385(9,31 \%)$ & $3.888(90,69 \%)$ & 0,21 \\
\hline \multicolumn{4}{|l|}{ Status Sosial-Ekonomi } \\
\hline Rendah & $97(24,52 \%)$ & $283(75,48 \%)$ & \\
\hline Menengah-Tinggi & $811(8,79 \%)$ & $8.437(91,21 \%)$ & 0,0001 \\
\hline \multicolumn{4}{|l|}{ Bullying } \\
\hline $\mathrm{Ya}$ & $357(19,01 \%)$ & $1.568(80,99 \%)$ & \\
\hline Tidak & $551(6,98 \%)$ & $7.152(93,02 \%)$ & 0,0001 \\
\hline
\end{tabular}

\section{Pembahasan}

Prevalensi remaja pada penelitian ini yang mengalami gangguan kesehatan mental pada penelitian ini adalah 9,4\%, lebih kecil dibandingkan prevalensi gangguan kesehatan mental emosional pada remaja usia $>15$ tahun pada Riskesdas tahun $2018(9,8 \%)$ dan lebih tinggi jika dibandingkan dengan hasil Riskesdas tahun $2013(6 \%) .{ }^{14}$ Sedangkan dalam penelitian cross-sectional Mubasyiroh dkk menunjukkan prevalensi gejala mental emosional sebesar 
$60,17 \%$, lebih tinggi dibandingkan prevalensi pada penelitian ini. ${ }^{12}$ Selain itu prevalensi kecemasan, kesepian dan upaya bunuh diri pada remaja di Namibia secara berturut adalah $14,5 \%, 22,7 \%$ dan $22,7 \%$, lebih tinggi dari prevalensi komposit gangguan kesehatan mental pada penelitian ini. ${ }^{15}$ Berdasarkan analisis multivariat tahap akhir, hubungan gaya hidup dengan kesehatan mental remaja di Indonesia tahun 2015 memiliki asosiasi PR sebesar 1,47 (95\%CI: 1,31 - 1,65) setelah dikontrol dengan jenis kelamin, status sosialekonomi dan bullying. Penelitian crosssectional hampir serupa dilakukan oleh Peltzer dan Pengpid di Namibia tahun 2015 menunjukkan bahwa terdapat hubungan gaya hidup dengan kesehatan mental yang terbagi dalam 3 kategori, yaitu kecemasan, kesepian dan ide bunuh diri. Asosiasi gaya hidup dengan kecemasan pada remaja sekolah di Namibia tahun 2015 adalah 1,15 (95\%CI: 1,05-1,27), dengan kesepian sebesar 1,15 (95\%CI: 1,071,24) dan dengan upaya percobaan bunuh diri sebesar 1,11 (95\%CI: 1,03-1,20). ${ }^{15}$ Sejalan juga dengan penelitian yang dilakukan Rao et al. asosiasi gaya hidup dengan kecemasan adalah sebesar 1,81 (95\%CI: 1,22-2,70) dan asosiasi gaya hidup dengan keinginan bunuh diri sebesar 3,03 (95\%CI: $1,57-5,84) .{ }^{16}$ Penelitian ini menunjukkan bahwa gabungan efek dari perilaku gaya hidup tidak sehat memiliki hubungan yang kuat dengan gangguan kesehatan mental berupa kecemasan, kesepian dan upaya bunuh diri. Selain itu, terdapat kemungkinan meningkatnya masalah kesehatan mental dengan meningkatnya jumlah perilaku gaya hidup tidak sehat.

Tabel 5. Hasil Model Akhir Gaya Hidup Setelah Dikontrol dengan Seluruh Kovariat

\begin{tabular}{lcccc}
\hline \multicolumn{1}{c}{ Variabel } & PR & SE & 95\% CI & P-value \\
\hline Gaya Hidup (tidak sehat) & 1,47 & 0,085 & $1,31-1,65$ & 0,0001 \\
Jenis Kelamin (perempuan) & 1,17 & 0,085 & $1,01-1,35$ & 0,032 \\
Status Sosial-Ekonomi (rendah) & 2,32 & 0,197 & $1,96-2,76$ & 0,0001 \\
Bullying (ya) & 2,56 & 0,184 & $2,21-2,97$ & 0,0001 \\
\hline
\end{tabular}

Berdasarkan penelitian korelasional cross-sectional dan deskriptif yang dilakukan Yoo dan Kim (2020) konsumsi alkohol berhubungan persepsi stress, gangguan mood dan ide bunuh diri. Selain itu terdapat pula hubungan perilaku menetap dengan persepsi stress. ${ }^{17}$ Dalam Nurwijaya dan Ikawati (2009), alkohol ini memiliki efek buruk terhadap otak bagian hipokasmus. Bagian ini sangat penting selama masa remaja karena berhubungan dengan memori, proses belajar dan regulasi emosi. $^{18}$

Perilaku menetap secara signifikan berhubungan dengan persepsi stress. Waktu menetap telah diketahui memiliki hubungan dengan kesehatan mental emosional remaja. Dalam penelitian Dendup disebutkan bahwa remaja yang melaporkan rasa kesepian dan keinginan bunuh diri lebih cenderung tidak berpindah atau memiliki perilaku yang menetap. ${ }^{11}$ Remaja yang berada di kelas yang lebih tinggi memiliki peluang yang lebih besar untuk berada pada keadaan menetap (perilaku menetap). Remaja di kelas lanjutan mungkin memiliki lebih banyak mata pelajaran akademis/modul untuk dilakukan, tekanan akademis yang lebih besar dan terkait stres yang dapat memperpanjang waktu duduk dan menggantikan waktu aktivitas fisik. ${ }^{9}$

Penelitian cross-sectional yang dilakukan Tanihata et al. menunjukkan bahwa remaja yang merokok memiliki risiko 1,5 kali untuk mengalami gangguan kesehatan mental. ${ }^{19}$ Gaya hidup yang tidak sehat seperti konsumsi alkohol dan merokok meningkatkan risiko keinginan bunuh diri. ${ }^{7}$ Selanjutnya, merokok memiliki hubungan signifikan dengan depresi pada remaja di Korea. Perokok berisiko 1,3 kali lebih besar untuk mengalami depresi dibanding nonperokok. Selain itu, perokok memiliki risiko 1,5 kali lebih besar untuk mengalami kecemasan dibandingkan non-perokok $(0<0,05) .{ }^{20}$ Berdasarkan penelitian Koivusilta et al. merokok mungkin merupakan tanda stres yang disebabkan oleh kelebihan beban pengembangan pribadi dan sosial atau 
kegagalan untuk memenuhi harapan peran sosial. Tekanan untuk berhasil secara akademis telah diidentifikasi sebagai sumber stres yang penting bagi remaja. Merokok dikaitkan dengan berbagai macam masalah kesehatan mental, seperti depresi. Hal ini menunjukkan bahwa perilaku gaya hidup berisiko, masalah kesehatan dan kurangnya sumber daya untuk pencapaian pendidikan mungkin terkait erat sudah pada tahap awal kehidupan remaja. ${ }^{21}$

Konsumsi buah dan konsumsi sayur pada penelitian ini memiliki efek protektif dengan gangguan kesehatan mental remaja. Penelitian meta-analisis yang dilakukan Liu et al (2016) menunjukkan bahwa terdapat asosiasi terbalik konsumsi buah dengan depresi. ${ }^{22}$ Studi crosssectional yang dilakukan Hong dan Peltzer (2017) juga menyatakan bahwa asupan buah, sayur dan sarapan secara teratur (perilaku diet sehat) terbukti secara positif berhubungan dengan berhubungan negatif dengan stres yang dirasakan, tekanan mental dan depresi. ${ }^{23}$

Konsumsi minuman bersoda berhubungan dengan kesehatan mental remaja. Berbanding terbalik dengan penelitian yang dilakukan Jacob et al (2020) konsumsi minuman berkarbonasi sekali sehari dalam 30 hari terakhir tidak memiliki hubungan dengan gangguan kesehatan mental. Namun terdapat hubungan antara konsumsi minuman berkabornasi dengan kesehatan mental jika remaja mengkonsumsi minuman berkarbonasi 3 kali sehari dalam 30 hari terakhir. ${ }^{24}$ Konsumsi minuman bersoda sering berhubungan dengan kesulitan tidur, gangguan tidur dan ketidakpuasaan kualitas tidur. Kandungan gula yang tinggi pada minuman bersoda dapat mempengaruhi suasana hati dan meningkatkan gejala depresi. yang berhubungan dengan masalah tidur di kalangan remaja. Gula yang ditambahkan dapat menggantikan konsumsi makanan kaya nutrisi mikro, yang penting untuk kesejahteraan mental remaja. Selain itu, minuman ringan sering kali mengandung kafein, yang dikenal sebagai stimulan dan berkaitan dengan masalah kurang tidur, gangguan tidur, dan kantuk di siang hari di kalangan remaja. ${ }^{25}$

Penelitian cross-sectional Park et al. (2018), di Korea Selatan remaja yang mengkonsumsi makanan cepat saji atau minuman ringan yang berlebih memiliki kemungkinan untuk merasakan kepuasan tidur 0,81 kali lebih rendah. Konsumsi makanan cepat saji berhubungan dengan kesehatan fisik dan mental yang buruk. Sering mengkonsumsi makanan cepat saji memiliki efek yang merugikan terhadap kesehatan fisik individu, seperti penyebab disfungsi endotel, peradangan, dan penyakit kardiovaskular. Kesehatan fisik yang menurun dapat memengaruhi kesehatan mental, misalnya depresi. Selain itu, konsumsi makanan cepat saji berkaitan dengan kebahagiaan rendah, depresi yang lebih tinggi, dan tekanan kejiwaan (yaitu kekhawatiran, depresi, kebingungan, insomnia, kecemasan, agresi, dan perasaan tidak berharga). Namun, stres dan depresi juga dapat meningkatkan konsumsi makanan cepat saji dan dapat menyebabkan masalah kesehatan fisik. ${ }^{26}$

Pada penelitian ini, faktor jenis kelamin berhubungan dengan gaya hidup dan kesehatan mental remaja. Hal ini sejalan dengan penelitian cross-sectional Mubasyiroh dkk menyebutkan bahwa remaja perempuan berisiko 1,9 kali lebih besar $\quad(\mathrm{OR}=1,9, \quad 95 \% \quad \mathrm{CI} \quad 1,67-2,16)$ dibandingkan remaja laki-laki. Remaja perempuan lebih berisiko untuk tenggelam dalam depresi. Perempuan sangat rentan terhadapnya gangguan makan seperti anoreksia dan bulimia, kerentanan ini berasal dari hubungan self-image remaja putri terutama bentuk tubuh yang negatif dan menjadi bagian dari kecemasan mendalam atas citra tubuh yang didorong oleh budaya dan stereotip media tentang kecantikan feminin. ${ }^{27}$ Dalam Santrock, masa puber yang terjadi pada remaja perempuan lebih cepat dibandingkan remaja laki-laki sehingga remaja perempuan lebih cenderung mengalami berbagai perubahan dari pengalaman dan masalah hidup. ${ }^{28}$ Berdasarkan penelitian Dendup, frekuensi perempuan untuk mengkonsumsi makanan cepat saji lebih besar dibanding laki. Hal serupa juga dengan frekuensi konsumsi minuman bersoda sering yang cenderung lebih besar pada perempuan. Kecenderungan risiko untuk mengalami gangguan kesehatan mental berupa upaya bunuh diri pada perempuan yang memiliki perilaku menetap tinggi 1,37 kali lebih tinggi dibanding dengan laki-laki. ${ }^{29}$ Pada penelitian Liu dkk (2015), kesepian merupakan determinan penting pada laki-laki sedangkan perilaku bunuh diri 
memiliki asosiasi lebih kuat pada perempuan dibanding pada laki-laki. Kesepian merupakan faktor penting dalam perilaku menetap di antara laki-laki karena laki-laki cenderung merasa kesepian dibandingkan perempuan. ${ }^{30}$

Pada penelitian ini status sosial-ekonomi (SSE) memiliki hubungan dengan gaya hidup dan kesehatan mental remaja. Hal ini sejalan dengan penelitian Evans et al. yang menyatakan bahwa remaja dengan SSE yang lebih rendah memiliki lebih banyak gejala masalah kesehatan mental. ${ }^{31}$ SSE yang rendah juga dikaitkan dengan perilaku gaya hidup yang berisiko. Dalam penelitian Koivusilta et al. disebutkan bahwa interaksi antara SES dan gaya hidup yang berhubungan dengan kesehatan mungkin timbul dari masalah ekonomi dan faktor kontekstual lainnya, misalnya makanan sehat yang cenderung lebih mahal sehingga membatasi kemungkinan masyarakat tidak mampu untuk menjaga pola makan yang sehat. ${ }^{21}$ Hal ini sejalan juga dengan studi yang dilakukan Escarce bahwa efek kumulatif dari SES pada keluarga, lingkungan, sekolah, dan perawatan kesehatan menjamin bahwa remaja yang tidak mampu dan berpenghasilan rendah saat di usia dewasa cenderung memiliki kesehatan yang lebih buruk, terlibat dalam perilaku yang lebih berisiko dan lebih berbahaya, dan dengan pencapaian pendidikan yang lebih rendah dan prospek karir yang lebih terbatas. ${ }^{32}$

Faktor bullying juga berhubungan dengan gaya hidup dan kesehatan mental remaja. Sejalan dengan tudi cross-sectional Hawker dan Bulton menyatakan bahwa anak-anak yang menjadi target bullying menunjukkan tandatanda kesulitan seperti depresi dan kecemasan ${ }^{33}$. Selain itu, studi Le et al. menyebutkan bahwa murid sekolah yang menjadi korban bullying memiliki lebih banyak gejala depresi dan tekanan psikologis, dan melaporkan ideasi bunuh diri dibandingkan siswa yang tidak terlibat bullying. Remaja yang mengalami tingkat bullying yang tinggi secara signifikan memiliki risiko untuk melakukan upaya bunuh diri. ${ }^{34}$ Dalam penelitian Turagabeci et al., perilaku gaya hidup memiliki hubungan dengan bullying. Merokok, konsumsi alkohol dan perilaku seksual yang aktif dapat meningkatan risiko untuk mengalami bullying dan kekerasan/cedera. Pencegahan merokok dan penggunaan alkohol selama remaja perlu dilakukan tidak hanya untuk mengurangi efek samping langsung terhadap kesehatan tetapi juga karena hubungan tidak langsung dengan masalah sosial, termasuk bullying dan kekerasan. Selain itu, manfaat nutrisi yang baik berimplikasi pada penurunan rasio risiko relatif terhadap sering mengalami bullying dan mengalami kekerasan baik pada perempuan maupun laki-laki. Nutrisi yang baik sangat penting untuk percepatan pertumbuhan selama remaja. ${ }^{35}$

Terdapat beberapa keterbatasan dalam penelitian ini, yaitu adanya temporal ambiguity karena penelitian ini menggunakan desain studi cross-sectional sehingga sulit menentukan hubungan sebab-akibat. Oleh karena itu, tidak dapat mengetahui antara eksposur dan outcome mana yang mendahului, yaitu mungkin remaja yang sudah mengalami gangguan kesehatan mental lebih berpotensi untuk mengadopsi gaya hidup tidak sehat seperti kebiasaan diet yang buruk, gaya hidup tidak aktif secara fisik, terlibat dalam merokok atau mengkonsumsi alkohol. Selain itu, pengumpulan data pada penelitian GSHS menggunakan sistem SRQ sehingga kemungkinan berpotensi memiliki bias informasi dan bias seleksi. Namun sifat anonim dari pengisian kuesioner GSHS ini diharapkan dapat meminimalisir bias yang terjadi. ${ }^{16}$ Selanjutnya, data mengenai kesehatan mental pada GSHS ini hanya berasal dari 1 pernyataan untuk setiap variabelnya sehingga bisa dikatakan cukup lemah. Akan tetapi dapat dijadikan sebagai gambaran untuk mengetahui kesehatan mental remaja sekolah di Indonesia.

\section{Kesimpulan}

Ada hubungan gaya hidup dengan kesehatan mental remaja di Indonesia tahun 2015 setelah dikontrol dengan jenis kelamin, status sosial-ekonomi dan bullying dengan PR 1,47 (95\%CI: $1,31-1,65)$. 


\section{Ucapan Terima Kasih}

Penulis mengucapkan terima kasih kepada WHO atas kesempatan yang diberikan untuk menganalisis data GSHS Indonesia 2015 dan semua pihak yang telah membantu dalam penelitian ini.

\section{Daftar Pustaka}

1. WHO. 2018. Adolescent Mental Health [Internet]. [cited 2021 Mar 31]. Available from: https://www.who.int/ newsroom/factsheets/detail/adolescent-mentalhealth.

2. Liu MW, Chen QT, Towne SD, Zhang J, $\mathrm{Yu}$ HJ, Tang R, et al. 2020. Fruit and vegetable intake in relation to depressive and anxiety symptoms among adolescents in 25 low- and middle-income countries. J Affect Disorders. 261:172-80.

3. Kusumawardani N, Rachmalina, Wiryawan Y, Anwar A, Handayani K, Mubsayiroh R, et al. 2015. Perilaku Berisiko Kesehatan pada Pelajar SMP dan SMA di Indonesia. Badan Litbangkes Kementrian Kesehatan Republik Indonesia.

4. Davies T, Craig T. 2009. ABC Kesehatan Mental. Jakarta: EGC.

5. Maenhout L, Maenhout L, Peuters C, Peuters C, Cardon G, Compernolle S, et al. 2020. The association of healthy lifestyle behaviors with mental health indicators among adolescents of different family affluence in Belgium. BMC Public Health. 20(1):1-14.

6. Yi X, Liu Z, Qiao W, Xie X, Yi N, Dong X, et al. 2020. Clustering effects of health risk behavior on mental health and physical activity in Chinese adolescents. Health Qual Life Out. 18(1):1-11.
7. Rodelli M, De Bourdeaudhuij I, Dumon E, Portzky G, DeSmet A. 2018. Which healthy lifestyle factors are associated with a lower risk of suicidal ideation among adolescents faced with cyberbullying? Prev Med. 113:32-40.

8. Cairns KE, Yap MBH, Pilkington PD, Jorm AF. 2014. Risk and protective factors for depression that adolescents can modify: A systematic review and meta-analysis of longitudinal studies. J Affect Disorders. $169: 61-75$.

9. Ferreira RW, Rombaldi AJ, Ricardo LIC, Hallal PC, Azevedo MR. 2016. Prevalence of sedentary behavior and its correlates among primary and secondary school students. Revista Paulista de Pediatria. 34(1):56-63.

10. Atzendorf J, Apfelbacher C, Gomes De Matos E, Kraus L, Piontek D. 2018. Patterns of multiple lifestyle risk factors and their link to mental health in the German adult population: A cross-sectional study. BMJ Open. 8(12).

11. Dendup T, Putra IGNE, Dorji T, Tobgay T, Dorji G, Phuntsho S, et al. 2020. Correlates of sedentary behaviour among Bhutanese adolescents : Findings from the 2016 Global School-based health survey. Child Youth Serv Rev. 119.

12. Mubasyiroh R, Suryaputri IY, Tjandrarini DH. 2017. Determinan Gejala Mental Emosional Pelajar SMP-SMA di Indonesia Tahun 2015. Buletin Penelitian Kesehatan. 45(2).

13. Hasumi T, Ahsan F, Couper CM, Aguayo JL, Jacobsen KH. 2012. Parental involvement and mental well-being of Indian adolescents. Indian Pediatr. 49(11):915-8. 
14. Kemenkes RI. 2018. Laporan Nasional RISKESDAS 2018. p. 583.

15. Peltzer K, Pengpid S. 2017. Lifestyle and mental health among school-going adolescents in namibia. $\mathrm{J}$ Psychol Afr. 27(1):69-73.

16. Rao S, Shah N, Jawed N, Inam S, Shafique K. 2015. Nutritional and lifestyle risk behaviors and their association with mental health and violence among Pakistani adolescents : Results from the National Survey of 4583 individuals Health behavior, health promotion and society. BMC Public Health. 15(1):1-10.

17. Yoo H, Kim N. 2020. Factors associated with lifestyle habits and mental health problems in korean adolescents: The Korea national health and nutrition examination survey 2017-2018. Int J Environ Res and Pu.17(24):1-15.

18. Nurwijaya H, Ikawati Z.2009. Bahaya Alkohol dan Cara Mencegah Kecanduannya. Jakarta: PT Elex Media Komputindo.

19. Tanihata T, Kanda H, Osaki Y, Ohida T, Minowa M, Wada K, et al. 2015. Unhealthy Lifestyle, Poor Mental Health, and Its Correlation Among Adolescents: A Nationwide Cross-Sectional Survey. AsiaPacific Journal of Public Health. 27(2).

20. Byeon H. 2015. Association among smoking, depression, and anxiety: Findings froma representative sample of Korean adolescents. PeerJ. 2015(10):1-12.

21. Koivusilta LK, Rimpelä AH, Rimpelä MK. 1999. Health-related lifestyle in adolescence - Origin of social class differences in health? Health Educ Res. 14(3):339-55.
22. Liu X, Yan Y, Li F, Zhang D. 2016. Fruit and vegetable consumption and the risk of depression: A meta-analysis. Nutrition. 32(3):296-302.

23. Hong SA, Peltzer K.2017. Dietary behaviour, psychological well-being and mental distress among adolescents in Korea. Child Adol Psych Men. 11(1):1-12.

24. Jacob L, Stubbs B, Koyanagi A. 2020. Consumption of carbonated soft drinks and suicide attempts among 105,061 adolescents aged 12-15 years from 6 highincome, 22 middle-income, and 4 lowincome countries. Clin Nutr. 39(3):886-92.

25. Khan A, Uddin R. 2020. Is consumption of fast-food and carbonated soft drink associated with anxiety-induced sleep disturbance among adolescents? A population-based study. Clin Nutr. 36 : $162-5$.

26. Park S, Rim SJ, Lee JH. 2018. Associations between dietary behaviours and perceived physical and mental health status among Korean adolescents. Nutrition and Dietetics. 75(5):488-93.

27. UNICEF. Early and late adolescence [Internet]. [cited 2021 May 24]. Available from:https://www.unicef.org/sowc2011/pd fs/Early-and-late-adolescence.pdf

28. Santrock JW. 2007. Adolescent Perkembangan Remaja (Alih Bahasa Shinto B. Adelar \& Sherly Saragih). Jakarta: Erlangga.

29. Dendup T, Putra IGNE, Dorji T, Tobgay T, Dorji G, Phuntsho S, et al. 2020. Correlates of sedentary behaviour among Bhutanese adolescents: Findings from the 2016 Global School-based health survey. Child Youth Serv Rev. 119:105520. 
30. Yen CF, Yang P, Wang PW, Lin HC, Liu TL, Wu YY, et al. 2014. Association between school bullying levels/types and mental health problems among Taiwanese adolescents. Compr Psychiat. 55 (3) : 405 13.

31. Boe T, Petrie KJ, Sivertsen B, Hysing M. 2019. Interplay of subjective and objective economic well-being on the mental health of Norwegian adolescents. SSM - Popul Health. 9:100471.

32. Escarce. 2003. Socioeconomic Status and the Fates of Adolescents. Health Serv Res.

33. Arseneault L, Bowes L, Shakoor S. 2010. Bullying victimization in youths and mental health problems: Much ado about nothing? Psychol Med. 40(5):717-29.

34. Le HTH, Nguyen HT, Campbell MA, Gatton ML, Tran NT, Dunne MP. 2017. Longitudinal associations between bullying and mental health among adolescents in Vietnam. Int J Public Health. 62(1):51-61.

35. Turagabeci AR, Nakamura K, Takano T. 2008. Healthy lifestyle behaviour decreasing risks of being bullied, violence and injury. PLoS ONE. 3(2):1-6. 